\title{
34. STRATIGRAPHY, DEPOSITIONAL ENVIRONMENT, AND DIAGENESIS OF SEDIMENTS AT SITE 700 INFERRED FROM DOWNHOLE MEASUREMENTS ${ }^{1}$
}

\author{
C. J. Mwenifumbo ${ }^{2}$ and J. P. Blangy ${ }^{3}$
}

\begin{abstract}
Paleoenvironmental and diagenetic features within pelagic carbonate-rich sediments at ODP Site 700 are described based on logging data. The logging suite consisted of natural gamma-ray spectrometry (total count and percent $\mathrm{K}, \mathrm{U}$, and Th logs), induction (deep, medium, and focused resistivity logs), and induced gamma-ray spectrometry $(\mathrm{Ca}, \mathrm{Si}, \mathrm{H}, \mathrm{Cl}, \mathrm{S}, \mathrm{Fe}, \mathrm{Al}$, and elemental yield ratio logs). The lithology encountered at this site shows progressive lithification with depth from soft oozes, nannofossil chalk, and indurated chalk finally to limestone. This progressive lithification is indicated on the induction and geochemical logs as a gradual decrease in conductivity and the porosity indicator ratio. The effects of diagenesis on the sediment column, other than compaction, are clearly indicated on the calcium elemental yield and induction resistivity logs. Increases in calcium yield (percent carbonate) correlate with a reduction in porosity suggesting calcite cementation. Uranium enrichment within the carbonates at this site may be a product of either diagenesis or depositional environment.
\end{abstract}

\section{INTRODUCTION}

Downhole logging measurements provide a nearly continuous record of variations in the physical and chemical properties of the sediments intersected by a hole. Changes in petrophysical parameters such as mineralogy, fluid composition, texture, and porosity provide information on the depositional and post-depositional processes of the sediment. Logging measurements are currently often used in sedimentology and stratigraphic analysis (Serra and Abbott, 1982 ) and in the analysis of depositional environments and diagenesis (Fertl, 1979; Serra, 1986; Doveton, 1986). Different types of clays and certain minerals that contain radioactive elements $(\mathrm{K}, \mathrm{U}$, and $\mathrm{Th})$ are, for instance, characteristic of specific environments and have been extensively used in the study of depositional environments (Adams and Weaver, 1958; Hassan et al., 1976; Fertl, 1979, 1983). One of the major effects of diagenesis on sediments is a change in porosity, and a number of logging measurements (neutron porosity, density, electrical resistivity, porosity indicator ratio from the geochemical logging data, etc.) give distinct responses to porosity changes.

Ocean Drilling Program (ODP) Site 700 is in the western region of the East Georgia Basin $\left(51^{\circ} 31.992^{\prime} \mathrm{S}, 30^{\circ} 16.697^{\prime} \mathrm{W}\right)$, on the northeastern slope of the Northeast Georgia Rise in a water depth of $3601 \mathrm{~m}$. Logging was carried out in Hole 700B, which was rotary drilled to a total depth of $489 \mathrm{~m}$ below seafloor (mbsf) with approximately $50 \%$ average core recovery. Although Hole $700 \mathrm{~B}$ was drilled to $489 \mathrm{mbsf}$, logging measurements were only carried out in the open hole from 132.5 to $450 \mathrm{mbsf}$. This section of the hole intersects nannofossil chalk and limestone of Late Cretaceous to middle Eocene age. One of the objectives at this site was to relate the logging measurements to depositional environment and diagenesis within this predominantly pelagic

\footnotetext{
${ }^{1}$ Ciesielski, P. F., Kristoffersen, Y., et al., 1991. Proc. ODP. Sci. Results, 114: College Station, TX (Ocean Drilling Program).

${ }^{2}$ Mineral Resources Division, Geological Survey of Canada, 601 Booth Street, Ottawa, Ontario, Canada K1A 0E8.

${ }^{3}$ Department of Geophysics, Stanford University, Stanford, CA 94305 (Present address: Unocal Science and Technology, 376 S. Valencia Avenue, Brea, CA 92621).
}

carbonate sequence. The logging measurements also proved to be useful in defining lithostratigraphic boundaries in zones of poor core recovery.

\section{LOGGING MEASUREMENTS}

The Schlumberger logging suites consisted of the natural gamma-ray spectrometry tool (NGT), induced gamma-ray spectroscopy tool (GST), aluminum clay tool (ACT), and dual induction tool (DIPH). The NGT uses the gamma spectrometry technique for quantitative determinations of potassium, uranium, and thorium in formations encountered in a borehole. The four logs acquired with the NGT include the total count gamma-ray log that monitors the total radioactivity from the three radioactive elements, the potassium $\log (\mathrm{wt} \% \mathrm{~K})$, the uranium $\log$ (equivalent $U$ in $\mathrm{ppm}$ ), and the thorium $\log$ (equivalent Th in ppm). The GST is a neutron activation tool for the evaluation of elemental concentrations of the subsurface formations. Although quantitative elemental concentrations may be derived (Hertzog, 1988), the present GST data provide information only on the relative proportions of six elements ( $\mathrm{Ca}, \mathrm{Si}, \mathrm{H}, \mathrm{Cl}, \mathrm{S}$, and $\mathrm{Fe}$ ), which sum to 1 . The elemental yields therefore provide a qualitative variation in elemental composition along the borehole. The ACT tool has californium source that primarily activates aluminum and manganese. If properly calibrated, this tool gives absolute elemental concentrations of $\mathrm{Al}$ ( $\mathrm{wt} \%$ ); only relative variations in Mn are determined. The DIPH tool provides three resistivity logs: deep, medium, and focused.

Application of natural gamma-ray logs has been primarily in lithologic identification, determination of clay type and content (based on $\mathrm{K}, \mathrm{U}$, and $\mathrm{Th}$ and $\mathrm{Th} / \mathrm{K}$ and $\mathrm{Th} / \mathrm{U}$ ratios), and evaluation of depositional environment (U). The interpretation of the GST data in the present study is qualitative and consists of using the $\mathrm{Ca}$ yield and elemental yield ratios for lithologic identification (lithology indicator ratio, $\mathrm{LIR}=\mathrm{Si} /[\mathrm{Si}$ $+\mathrm{Ca}]$ ), porosity estimates (porosity indicator ratio, PIR = $\mathrm{H} /[\mathrm{Si}+\mathrm{Ca}]$ ), and iron estimates (iron indicator ratio, IIR = $\mathrm{Fe} /[\mathrm{Si}+\mathrm{Ca}])$. Variations in $\mathrm{Ca}$ yield provide a qualitative indication of variations in carbonate abundance. The LIR is used as an indicator of the abundance of quartz and silica relative to calcite. This assumes the absence of clays, which tend to complicate the interpretation of the LIR data. The PIR 
reflects the total amount of free water (pore space) plus bound water (in clay minerals) via variations in the measured hydrogen content. The IIR is a good measure of the total iron concentration in the formation, provided there is no significant variation in the aluminum content in clay, which interferes with the estimation of Fe. Natural gamma-ray logs may be used to delineate clay zones and thus make corrections for the effect of clay in the PIR, LIR, and IIR.

Resistivity variations within carbonate sediments are primarily a function of the temperature, pressure, porosity, and salinity of pore fluids. The presence of clay minerals, however, decreases the resistivity of the formation. Although apparent porosities are usually determined from resistivity data using Archie's law (Archie, 1942), these determinations are only approximate because variations in borehole diameter and clay content affect the apparent resistivities.

In summary, these suites of logs provide proxy data on downhole variations in elemental and mineralogical composition and the porosity in the sediments. These variations are derived from the natural gamma-ray and induced gamma-ray spectrometry logs. Porosity information is derived from the induction and PIR logs.

\section{LITHOSTRATIGRAPHY AND LOGGING MEASUREMENTS}

The sediments at Site 700 consist primarily of pelagic carbonates composed essentially of foraminifers and calcareous nannofossils (Ciesielski, Kristoffersen, et al., 1988). Some clay and volcanic ash occur within the lowermost lithostratigraphic units. The carbonates show a gradual change with depth from soft ooze through friable chalk, indurated chalk, and finally to limestone. These lithostratigraphic units represent progressively increasing diagenesis with depth. A description of the five lithostratigraphic units identified on the basis of diagenetic evolution and sedimentology is summarized in Figure 1, along with age and depth intervals (Ciesielski, Kristoffersen, et al., 1988).

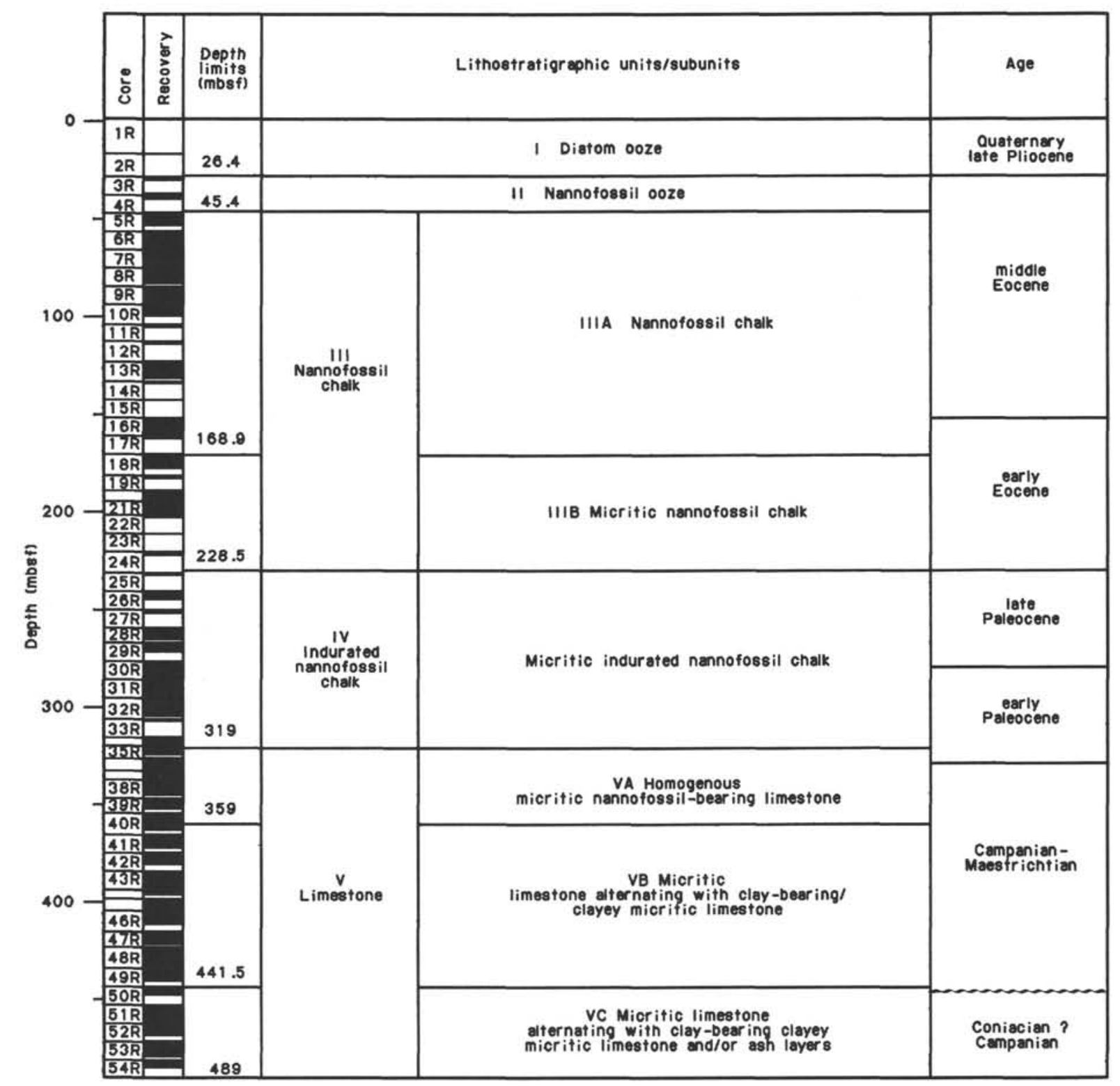

Figure 1. Lithostratigraphic units in Hole 700B. 


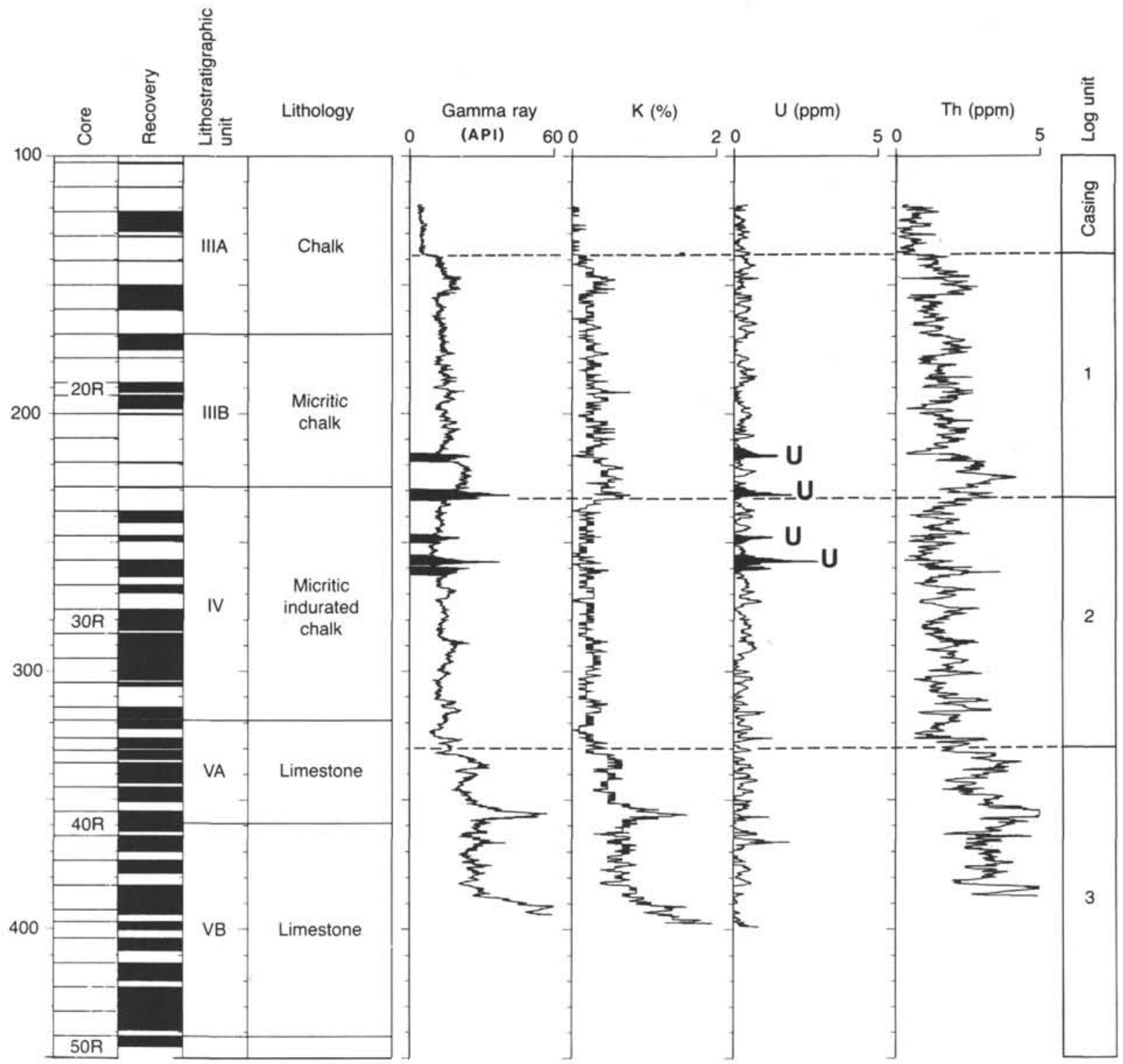

Figure 2. Natural gamma-ray spectral logs recorded in Hole 700B.

The logging data presented in Figures 2, 3, and 4 show the relationship between the logs and stratigraphy. Figure 2 shows the total count gamma-ray, K, U, and Th logs from the natural gamma-ray spectrometry tool. Three major lithologies recognized from the variations in the natural radioactivity correspond fairly well with lithostratigraphic Units III and IV and Subunit VA. Figure 3 shows the total count gamma-ray and the LIR, IIR, and PIR elemental yield ratio logs. Three major log units are again easily distinguished from the ratios, and these correlate well with those derived from the gamma-ray spectral logs. Figure 4 shows a comparison of gamma-ray, conductivity, PIR, and Ca yield data and the major subdivisions of the lithology based on these measurements (referred to as "log units").

$\mathrm{K}$ and $\mathrm{Th}$ increase toward the bottom of lithostratigraphic Subunit IIIB, suggesting an increase in clay content (Fig. 2). The Unit III/IV boundary is marked by a $U$ and conductivity anomaly. The conductivity steadily decreases downward within Unit III to a minimum at the boundary and then starts to increase (log Unit 2A, Fig. 4). Both the conductivity and PIR data show the same change within Subunit IIIB. Figure 5 shows a crossplot of the conductivity vs. PIR in lithostratigraphic Unit III. The good correlation between these two parameters indicates that we have two independent estimates of porosity.

There is an excellent correlation among conductivity, PIR, and $\mathrm{Ca}$ yield within the micritic indurated chalk of lithostratigraphic Unit IV. High $\mathrm{Ca}$ at the top and bottom of the unit correlates with a decrease in conductivity and PIR. The crossplot in Figure 6 of $\mathrm{Ca}$ yield vs. PIR illustrates the high degree of correlation between these parameters, suggesting that porosity may be influenced by $\mathrm{Ca}$. Within the indurated chalk and limestone, microcrystalline carbonate fills interstitial voids, suggesting recrystallization and secondary calcite overgrowth (Ciesielski, Kristoffersen, et al., 1988). Lithostratigraphic Unit IV appears to be homogeneous based upon the lack of variation in the $\mathrm{K}, \mathrm{U}, \mathrm{Th}$, and LIR logs. However, the electrical conductivity, PIR, and $\mathrm{Ca}$ yield logs indicate that 


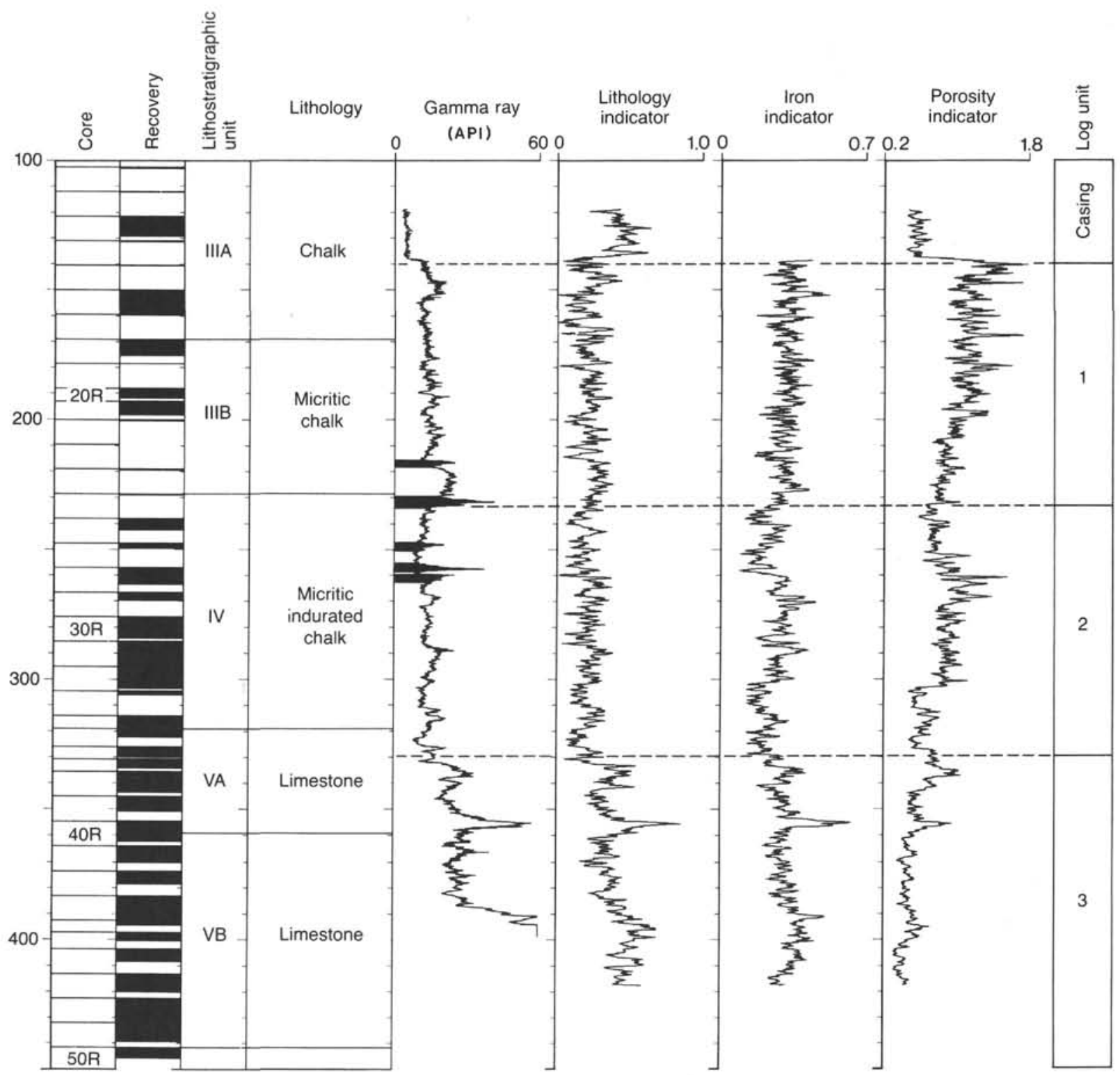

Figure 3. Elemental yield ratios from the induced gamma-ray spectrometry tool recorded in Hole 700B. Shown are the total count gamma-ray, lithology indicator ratio, iron indicator ratio, and porosity indicator ratio.

this unit may be further subdivided into three intervals (Fig. 4). The variations in these parameters probably reflect changes in porosity due to diagenesis (see "Diagenesis and Logging Measurements"' section).

\section{DEPOSITIONAL ENVIRONMENT AND LOGGING MEASUREMENTS}

Well log responses are interpreted in terms of geological parameters such as mineralogy (clay type and abundance), texture (grain size), and sedimentary features (porosity). These geological parameters provide some insight into the depositional environment. The natural gamma-ray and induced gamma-ray spectrometry logs provide the most significant information relating to depositional environment.

Because radioactivity is generally low in most carbonate-rich sediments (Fertl, 1983), any increases in potassium (assuming the absence of $\mathrm{K}$-feldspars) and thorium content in these sediments may be related to increases in the clay mineral fraction. A number of clay-rich sections have relatively high $\mathrm{K}$ and $\mathrm{Th}$ (e.g., between 220 and 235 mbsf, and in Subunits VA and VB). These clay-rich intervals may be due to carbonate dissolution or increased influx of terrigenous material during deposition.

Most carbonate rocks are generally low in uranium (Fertl, 1979). Uranium is very mobile in nature but tends to concentrate under reducing environments. The uranium concentration between 230 and 240 mbsf (Fig. 2) at the bottom of lithostratigraphic Subunit IIIB has a corresponding increase in conductivity. This interval is interpreted to be within a clayey section (210-240 mbsf) because of the relatively high $\mathrm{K}$ and Th concentrations and may indicate a reducing environment. Clays easily adsorb $U$ in reducing environments, particularly in the presence of carbonaceous material (Hassan et al., 1976). Measurements of organic carbon were not carried out in this interval; therefore, these geophysical observations can not be substantiated. There was also virtually no core recovery in this interval (Cores 114-700B-23R through 114-700B-25R). 


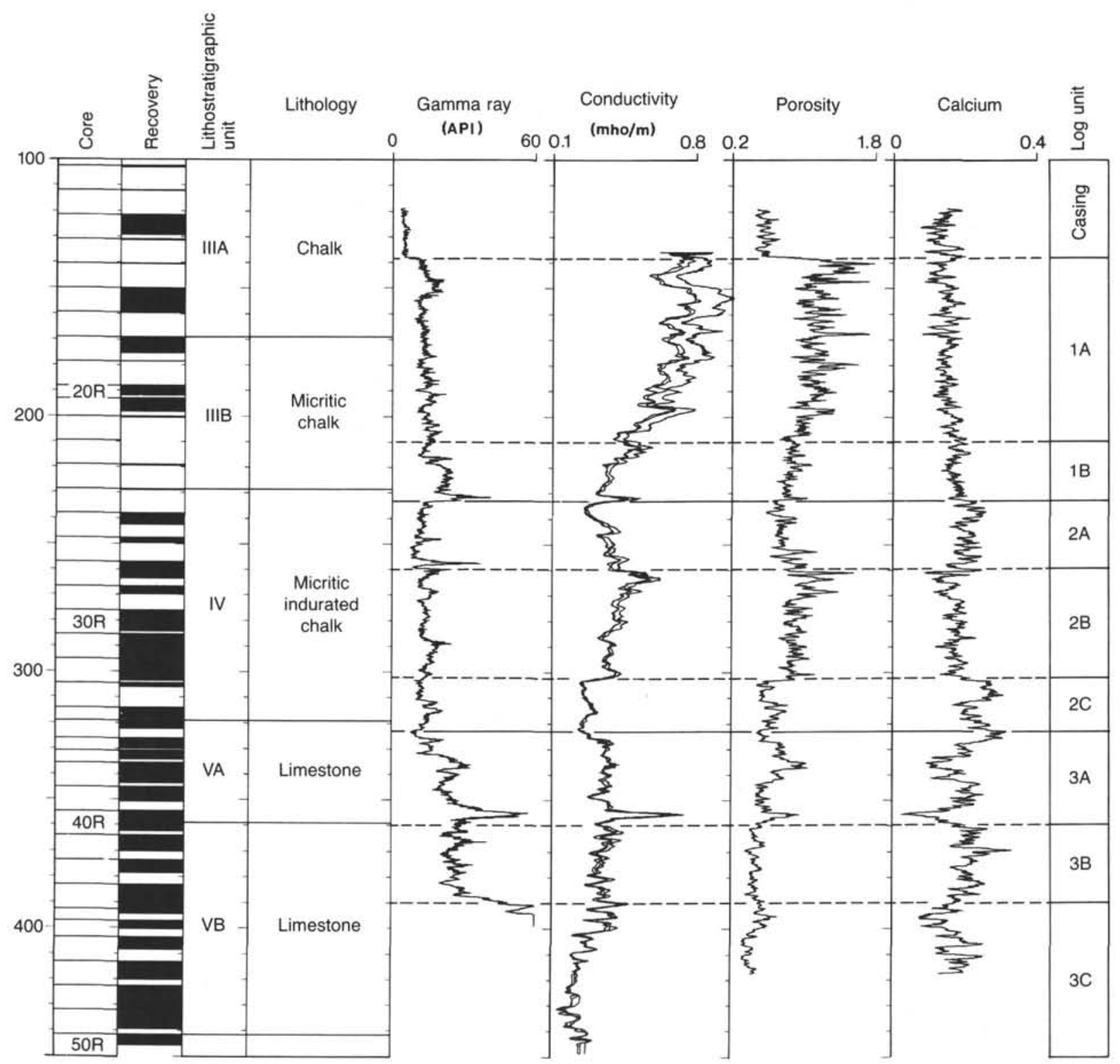

Figure 4. Stratigraphic units determined from gamma-ray, conductivity, porosity indicator ratio, and calcium yield logs compared with lithostratigraphic units.

the uranium anomalies between 240 and $260 \mathrm{mbsf}$ in the aicritic indurated chalk are low in both $\mathrm{K}$ and Th concentraions, suggesting that they are low in clay mineral content and nay therefore be products of diagenesis (see "Diagenesis and Jogging Measurements"' section).

Most of the logs indicate a prominent change in the physical nd geochemical signature of the sediments at approximately 330 absf. The LIR, IIR, aluminum (not shown), and gamma-ray alues increase, suggesting an increase in silica and clay content. his sudden change in the log responses correlates with a hiatus $t$ the Cretaceous/Tertiary boundary. The location roughly coresponds to the lithostratigraphic Subunit IV/VA boundary at pproximately 319 mbsf. The gradational nature of the contact retween the chalk of Subunit IV and limestone of Subunit VA any account for the 11-m discrepancy between the log unit and thostratigraphic boundary location.

The gamma-ray, conductivity, LIR, and Ca logs (Fig. 4) learly indicate the alternating clay-bearing limestone, clayey limestones, and limestones in lithostratigraphic Unit $\mathrm{V}$. These probably reflect fluctuations in the influx of terrigenous material related to changes in climate or to tectonic events. The claystone interval at 357 mbsf (Core 114-700B40R) is characterized by high LIR, IIR, K, and Th and low $\mathrm{Ca}$ yield. The increase in conductivity and PIR at this interval is due to the presence of clay. Aluminum concentration is also high. This interval is probably a volcanic ash layer, and the sediments may contain higher concentrations of bentonite (illite-montmorillonite clays) formed by in-situ alteration of volcanic ash.

\section{DIAGENESIS AND LOGGING MEASUREMENTS}

Diagenesis is the sum total of the physical, chemical, and biochemical changes that affect a sedimentary sequence after its deposition. Three types of processes are involved in diagenesis: physical processes (compaction, pressure, and temperature), chemical processes (dissolution, alteration, and 


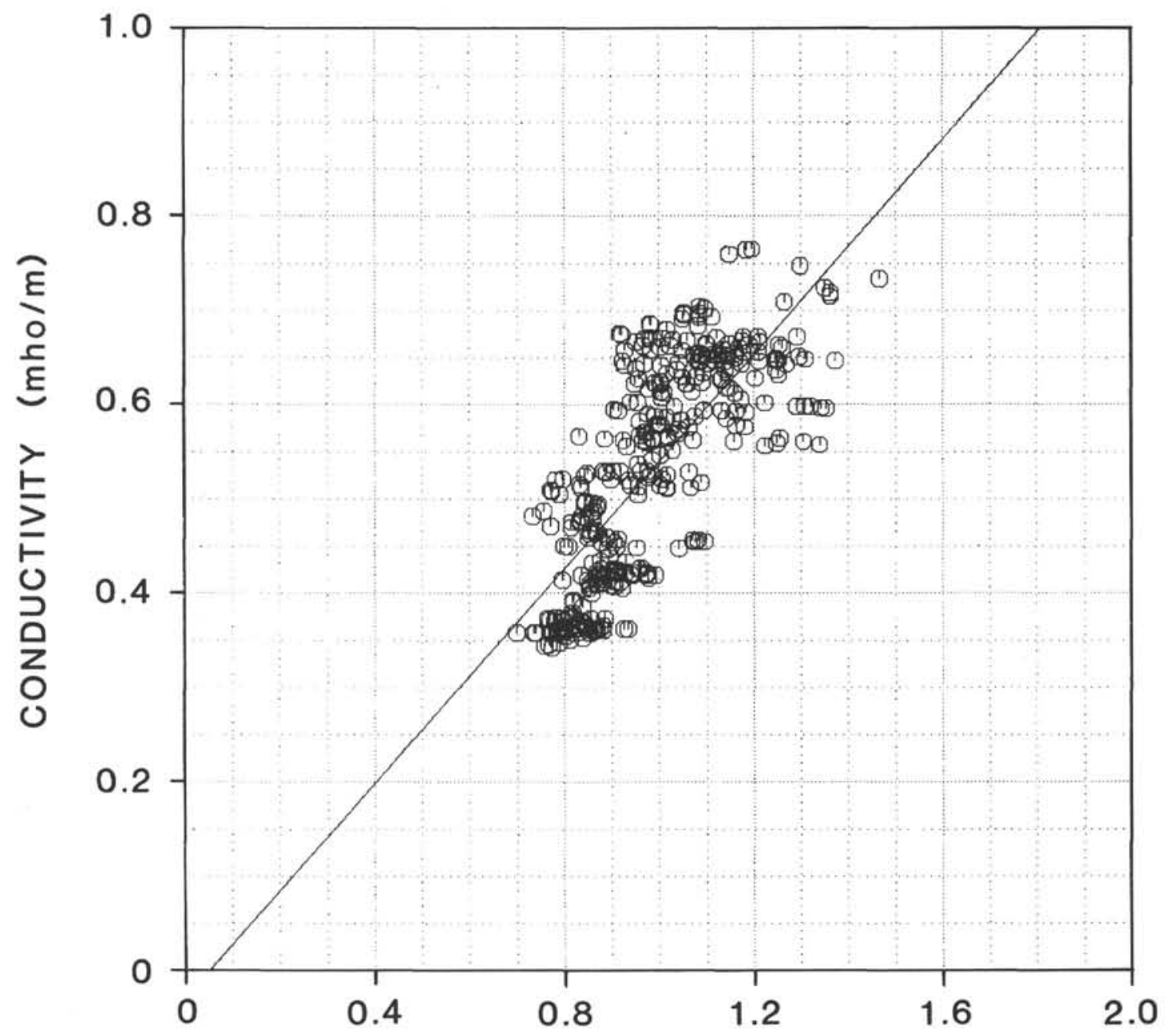

POROSITY INDICATOR RATIO

Figure 5. Relationship between conductivity and porosity indicator ratio within lithostratigraphic Unit III.

oxidation or reduction), and biological processes and actions of organisms (mixing of sediments through bioturbation). Compaction is simply the process of interstitial fluids being expelled due to overburden pressures, which results in lower porosity and fluid migration. As pressures and temperatures increase with depth, the chemical equilibrium conditions are modified; minerals stable at surface conditions may be out of equilibrium at higher pressures and temperatures. These conditions may result in either increased dissolution or increased precipitation of salts in the pore spaces. The effects of diagenesis on the properties of sediments also include changes in mineralogical composition through cementation, replacement, and authigenesis. Cementation is the deposition of minerals derived from migrating pore fluids containing dissolved salts. The most significant end result of both the physical and chemical diagenetic processes is a change in porosity.

The logs that respond to variations in porosity changes (PIR and electrical conductivity) show a gradual change throughout the logged interval. Both the conductivity and PIR steadily decrease with increasing depth, indicating a progressive diagenetic sequence (Fig. 4). This correlates with the lithostratigraphy describing a progressive lithification of the sediments with depth from soft ooze (Units I and II) to friable chalk (Unit III), indurated chalk (Unit IV), and finally to limestone (Unit V) (Ciesielski, Kristoffersen, et al., 1988). Within the transition from chalk to indurated chalk to limestone there is more microcrystalline carbonate, which fills interstitial voids, suggesting recrystallization and secondary calcite overgrowth. The development of chert at the bottom of Subunit VB is shown by a decrease in conductivity.

As stated in the previous sections, uranium is easily mobilized and may migrate during dissolution of carbonates. High uranium concentrations in carbonates are commonly associated with abundant stylolitic development (Serra et al., 1980). Although diagenesis influences the concentration and distribution of uranium in carbonate rocks (Adams and Weaver, 1956; Serra et al., 1980; Fertl, 1983), the uranium anomalies observed in Hole $700 \mathrm{~B}$ may not be conclusively attributed to this process because of the lack of supporting core data. The uranium anomaly at approximately $233 \mathrm{mbsf}$ correlates with an increase in conductivity, and there is also relatively high $\mathrm{K}$ and $\mathrm{Th}$ suggesting that it may be associated with clay minerals. Virtually no core was recovered in this section (Core 114-700B-25R) making it impossible to check the drill core data. The other uranium anomalies are low in both $\mathrm{K}$ and $\mathrm{Th}$ and may be a result of diagenesis or depositional environment. Uranium also tends to accumulate in faults or fractures (West and Laughlin, 1976; Fertl, 


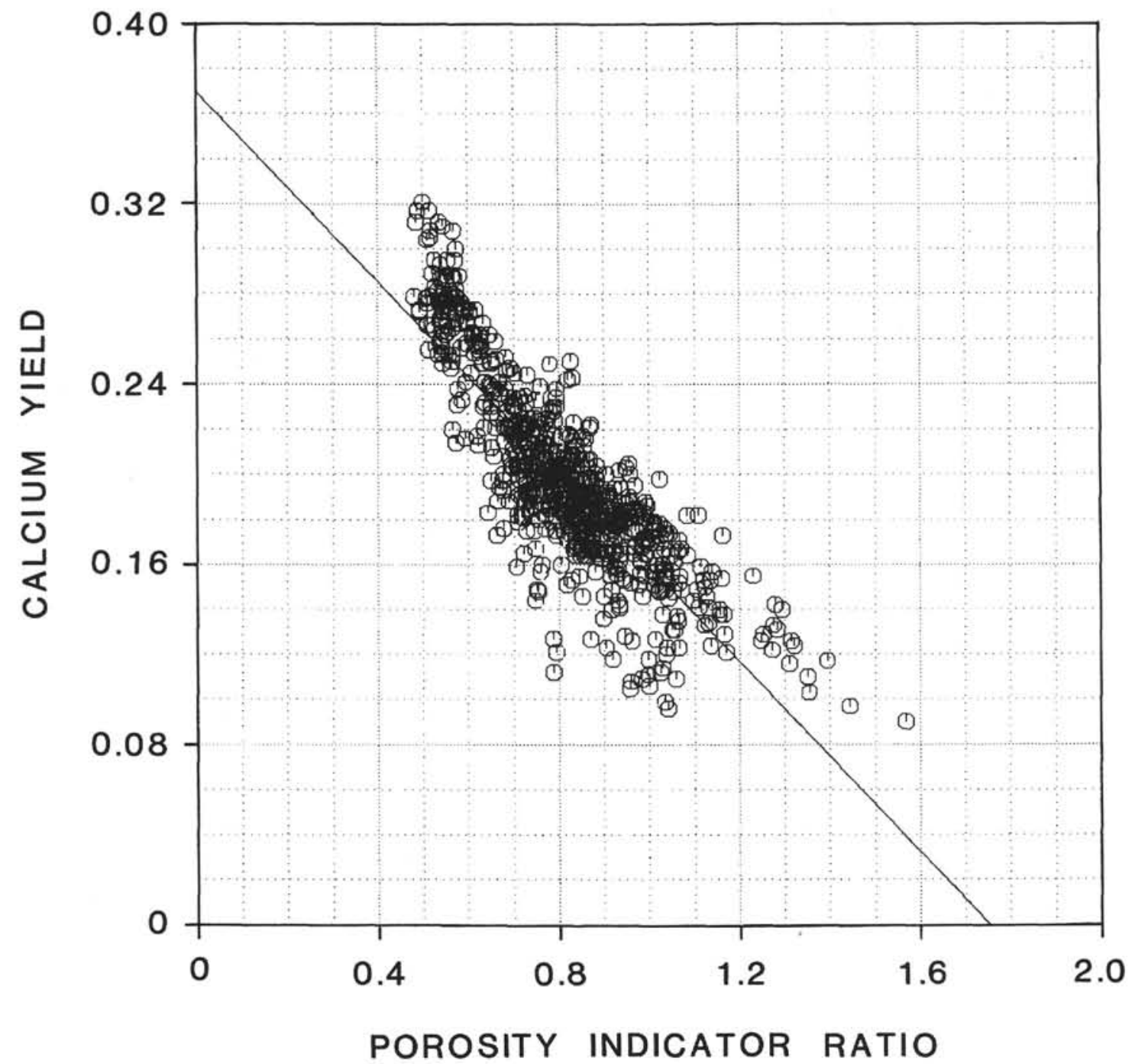

Figure 6. Relationship between calcium yield and porosity indicator ratio in lithostratigraphic Unit IV. Porosity is mainly controlled by calcium (percent carbonate).

1983). Core data between 245 and 265 mbsf, where some of these $\mathrm{U}$ anomalies occur, indicate slightly fractured core.

\section{CONCLUSIONS}

The pelagic carbonate sediments at Site 700 are characterized by low radioactivity except in the clay-rich intervals, which are characterized by increases in potassium and thorium. The presence of clay minerals within this predominantly carbonate environment reflects changes in depositional environment and/or source material. Clay-rich sections suggest periods of increased influx of terrigenous material. The logging data can provide some clues as to depositional environment and diagenetic changes in carbonate sediments. Intervals with anomalous concentrations of $U$ may reflect either a reducing depositional environment or diagenesis. Core data, however, are required to substantiate the interpretations from these observations. The overall decreasing trend in porosity with depth reflects normal compactional diagenetic changes along the sediment column.

\section{ACKNOWLEDGMENTS}

This is Geological Survey of Canada Contribution no. 14889.

\section{REFERENCES}

Adams, J.A.S., and Weaver, C. E., 1958. Thorium-to-uranium ratios as indicators of sedimentary processes: example of concept of geochemical facies. AAPG Bull., 42:387-430.

Archie, G. E., 1942. The electrical resistivity $\log$ as an aid in determining some reservoir characteristics. Trans. Am. Inst. Min. Metall. Pet. Eng., 146:54-67.

Ciesielski, P. F., Kristoffersen, Y., et al., 1988. Proc. ODP, Init. Repts., 114: College Station, TX (Ocean Drilling Program).

Doveton, J. H., 1986. Log Analysis of Subsurface Geology-Concepts and Computer Methods: New York (Wiley).

Fertl, W. H., 1979. Gamma ray spectral data assists in complex formation evaluation. Log Analyst, 20:421-423.

1983. Gamma ray spectral logging: a new evaluation frontier. Part II-Application in carbonates. World Oil, 196:8798.

Hassan, M., Hossin, A., and Combaz, A., 1976. Fundamentals of the differential gamma-ray log-interpretation techniques. Trans. SPWLA 17th Annu. Logging Symp., H1-H18.

Hertzog, R., 1988. Elemental Concentrations from Neutron Induced Gamma Ray Spectroscopy. IEEE Trans. Nucl. Sci., 35.

Serra, O., 1986. Fundamentals of Well Log Interpretation: Volume 2. The Interpretation of Logging Data: Amsterdam (Elsevier). 
Serra, O., and Abbott, H. T., 1982. The contribution of logging data to sedimentology and stratigraphy. Soc. Pet. Eng. AIME, Spec. Pap., J:117-131.

Serra, O., Baldwin, J., and Quiren, J., 1980. Theory, interpretation and practical applications of natural gamma-ray spectroscopy. Trans. SPWLA 21st Annu. Logging Symp., Q1-Q30.
West, F. G., and Laughlin, A. W., 1976. Spectral gamma logging in crystalline basement rocks. Geology, 4:617-618.

Date of initial receipt: 16 April 1989

Date of acceptance: 12 December 1989

Ms 114B-168 